\title{
Aspek Biologi Siganidae di Perairan Maluku
}

\author{
[Biological Aspects of Siganidae In Molucca Water] \\ Rafi Setiawan, Heri Triyono, Meuthia A. Jabbar
}

Sekolah Tinggi Perikanan Jalan AUP, Pasar Minggu 12520, DKI Jakarta

\begin{abstract}
Abstrak
Penelitian ini bertujuan untuk menganalisis aspek biologi Siganidae meliputi hubungan panjangberat, nisbah kelamin, tingkat kematangan gonad (TKG), ukuran pertama kali ikan tertangkap (LC) dan ukuran pertama kali ikan matang gonad (Lm). Penelitian dilakukan pada bulan Maret sampai dengan bulan Mei 2019 di Perairan Maluku. Metode penelitian untuk pengambilan ikan contoh menggunakan metode sensus yaitu dengan melakukan pengamatan atau observasi di lapangan terhadap sampel ikan yang didapatkan keseluruhan, Analisis hubungan panjang berat menggunakan Model allometric linear, rasio kelamin dilakukan dengan membandingkan jumlah antara ikan jantan dan betina per bulan dan kelas panjang. Analisis panjang ikan pertama kali tertangkap (LC) dianalisis berdasarkan metode Beverton dan Holt, 1957 dan Anasisis ukuran pertama kali matang gonad (Lm) dapat diduga dengan rumus Spearman-Karber.Hasil dari peneilitian ini $S$. lineatus dan $S$. canaliculatus memiliki pola pertumbuhan allometrik negatif. Nisbah kelamin pada $S$. lineatus dan $S$. canaliculatus berurutan yaitu 1:1,37 dan 1:1. Tingkat kematangan gonad yang diamati menggunakan TKG dari Cassie menunjukkan Siganus lineatus dan Siganus canaliculatus lebih dominan pada TKG V. Hasil analisis kondisi biologi menggunakan kurva logistik dan rumus Spearman-Karber mengindikasikan hasil tangkapan ikan $S$. lineatus didominasi ikan-ikan yang sudah memijah sedangkan pada $S$. canaliculatus didominasi ikan-ikan yang belum memijah.
\end{abstract}

Kata Kunci : biologi; Maluku; Siganus lineatus; Siganus canaliculatus

\section{Abstract}

The purpose of the research was to analyse the biological aspects of Siganidae including lengthweight relationship, sex ratio, gonadal maturity level (GML), length at first captured (LC) and length at first matury $(\mathrm{Lm})$ in Molucca. The results of this research were showed that $\mathrm{S}$. lineatus and $\mathrm{S}$. canaliculatus have negative allometric growth patterns. Sex ratio of $S$. lineatus and $S$. canaliculatus are respectively $1: 1,37$ and $1: 1$. The maturity level of gonads using GML criteria by Cassie (1956) showed that $\mathrm{S}$. lineatus and S. canaliculatus are more dominant in GML 5. The biological condition using logistic curve method and Spearman-Karber formula indicate of catch of $\mathrm{S}$. lineatus were dominated by mature fishes, but $\mathrm{S}$. canaliculatus dominated immature fishes.

Keyword : biology; Molucca; Siganus lineatus; Siganus canaliculatus

\section{Penulis Korespondensi}

Rafi Setiawan | rafikuns2@gmail.com

\section{PENDAHULUAN}

Maluku memiliki luas laut mencapai $658.294,69 \mathrm{~km}^{2}$ atau $92,4 \%$ dari luas wilayah Maluku secara keseluruhan
(Bank Indonesia 2007; Luhur dan Yusuf 2017). Maluku memiliki potensi sumberdaya perikanan sebesar 1,6 juta ton.tahun ${ }^{-1}$ dan jumlah tangkapan yang di 
perbolehkan (JTB) sebesar 1,3 juta ton.tahun ${ }^{-1}$ yang berasal dari 3 wilayah pengelolaan perikanan (WPP) yaitu, WPP 714, WPP 715 dan WPP 718 (Adam 2016; Bawole dan Apituley 2010; Dinas Penanaman Modal dan Pelayanan Terpadu Satu Pintu Provinsi Maluku 2012; Miftahussalam 2013). Sebagai Lumbung Ikan Nasional, Maluku merupakan produsen perikanan terbesar di Indonesia yang mampu memasok kebutuhan konsumsi masyarakat dan industri nasional dan menjadi eksportir utama komoditas perikanan Indonesia (Hikmayani dan Suryawati 2016; Suryawati dan Tajerin 2015).

Salah satu komoditas perikanan di Maluku yaitu ikan baronang (Siganidae). Di dunia terdapat 29 spesies dari famili Siganidae dalam satu genus Siganus (Froese dan Pauly 2018) yang pada tahun 1990 hanya ditemukan 27 spesies (Randall dan Kulbicki 2005; Woodland dan Anderson 2014). Di Indonesia terdapat 19 spesies, di antaranya Siganus argenteus, S. canaliculatus, $S$. corralinus, S. doliatus, $S$. fuscescens, $S$. guttatus, S. javus, S. lineatus, S. puellus, S. Puelloides, S. punctatissimus, $S$. punctatus, S. spinus, S. vermiculatus, $S$. virgatus, $S$. vulpinus, $S$. Sutor (Burhanudin, Budimawan, dan Sahabuddin 2014) S. magnificus, dan S. labyrinthodes (Froese dan Pauly 2018).
Ikan baronang

(Siganidae) merupakan jenis ikan karang yang mempunyai nilai ekonomis penting (Burhanuddin 2005; Pratomo et al. 2006; Tuegeh, Tilaar, dan Manu 2012), ditemukan di daerah terumbu karang dan lamun dan wilayah yang banyak terdapat rumput laut (Tuegeh et al. 2012; Turang, Watung, dan Lohoo 2019; WWFIndonesia 2015). Ikan baronang (Siganidae) memanfaatkan ekosistem padang lamun sebagai daerah asuhan (nursery ground), pemijahan (spawning ground), dan tempat mencari makanan (feeding ground) (Diane J. Bray 2019; Fakhri et al. 2016). Walaupun banyak yang tidak berasosiasi langsung dengan karang, tetapi pergerakannya kebanyakan berasosiasi dengan struktur khusus dan keadaan biotik dari karang (Rembet et al. 2011).

Aktivitas penangkapan terhadap ikan ini telah berlangsung lama dengan inovasi-inovasi pada alat tangkap yang dapat meningkatkan hasil tangkapan sesuai dengan Maximum Sustainable Yield (MSY) (Malik 2013), namun demikian belum ada data yang resmi tentang hasil tangkapan ikan baronang maupun ikan-ikan lainnya yang ditangkap pada daerah lamun (Munira, Sulistiono, dan Zairion 2010). Penelitian ini bertujuan mengkaji tentang biologi terhadap ikan baronang di Provinsi Maluku. 


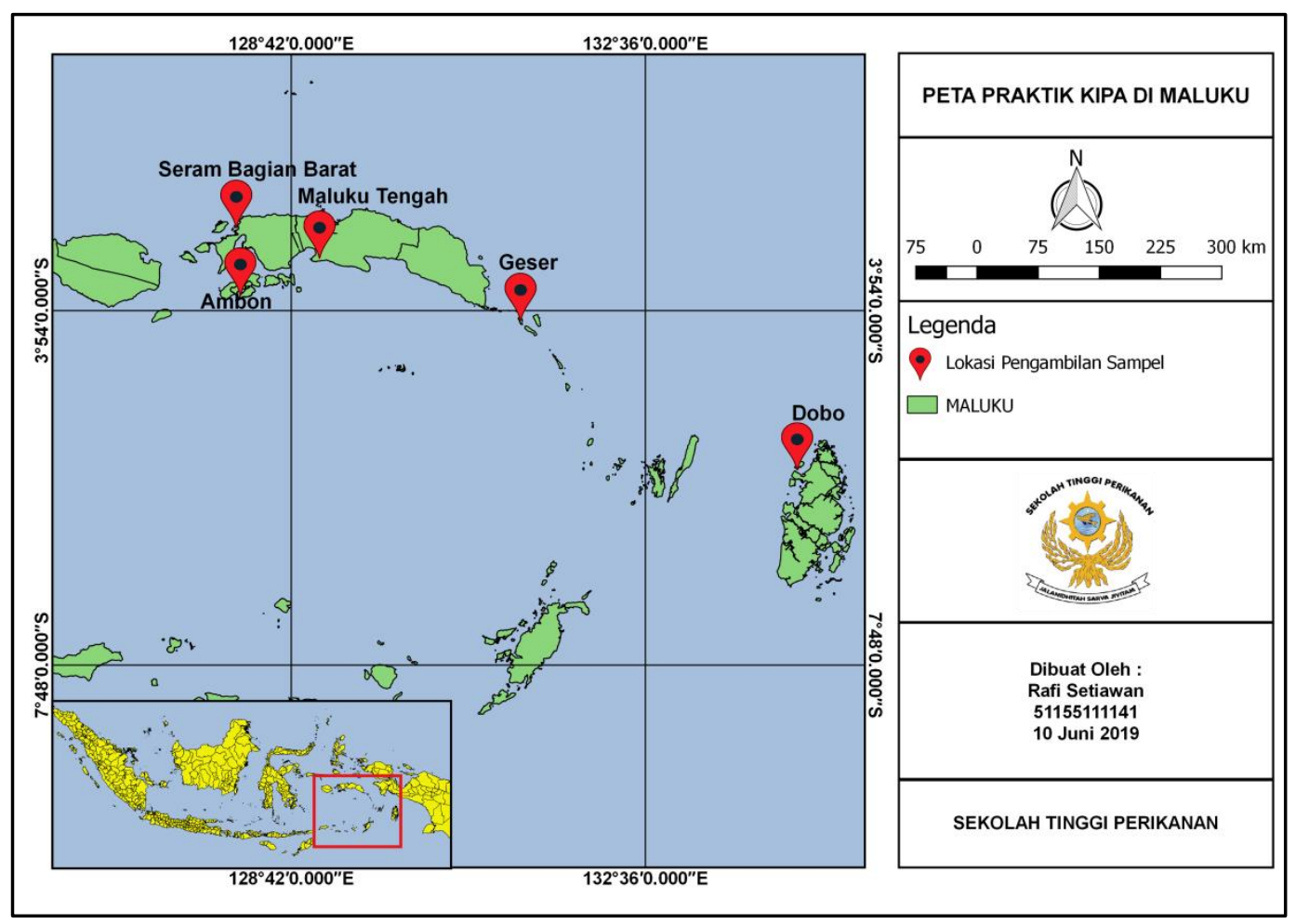

Gambar 1. Peta lokasi penelitian

Tabel 1. Alat dan bahan yang digunakan

\begin{tabular}{|c|c|c|}
\hline No & Alat dan Bahan & Spesifikasi \\
\hline 1 & Alat tulis & $\begin{array}{l}\text { Buku Paperline } 100 \text { halaman } \\
\text { Pulpen }\end{array}$ \\
\hline 2 & Alat pengukur panjang atau penggaris & Ketelitian $1 \mathrm{~mm}$; \\
\hline 3 & Timbangan & Ketelitian $1 \mathrm{gr}$ dan $0,1 \mathrm{gr}$ \\
\hline 4 & Disecting set & $\begin{array}{l}\text { Gunting } \\
\text { Pisau Bedah } \\
\text { Pinset Anatomis } \\
\text { Kaca Pembesar }\end{array}$ \\
\hline 5 & Kamera digital & 20.1 Megapixel \\
\hline 6 & Measuring board & Ketelitian $1 \mathrm{~mm}$; Panjang $60 \mathrm{~cm}$ \\
\hline 7 & Kuisioner & Kuisoner EAFM \\
\hline 8 & Ikan baronang (Siganidae) & Objek penelitian \\
\hline
\end{tabular}

\section{BAHAN DAN METODE}

Penelitian ini berlangsung pada tanggal 4 Maret sampai dengan 24 Mei
2019 di Provinsi Maluku. Lokasi pengambilan sampel ikan baronang terdiri dari 6 Kabupaten/Kota disajikan pada Gambar 1. Alat dan bahan yang 
digunakan selama penelitian di Maluku, dapat dilihat pada Tabel 1.

Pengambilan ikan menggunakan metode sensus yaitu dengan melakukan pengamatan atau observasi di lapangan terhadap sampel ikan yang didapatkan keseluruhan. Ikan contoh diperoleh dari hasil tangkapan nelayan yang beroperasi, pengumpul ikan dan beberapa pasar ikan yang ada di Provinsi Maluku.

Ikan contoh diukur dengan panjang standar sampai ketelitian 0,1 mm dan berat totalnya ditimbang sampai ketelitian $1 \mathrm{gram}$. Untuk mengetahui jenis kelamin dan tingkat kematangan gonad pada ikan, dilakukan pembedahan terhadap perut ikan. Kemudian gonad dilihat dan diidentifikasi berdasarkan jenis kelamin dan tingkatan masingmasing gonad. Identifikasi tingkatan kematangan gonad menggunakan metode Cassie dalam Latuconsina dan Wasahua (2015).

Analisis hubungan panjang berat menggunakan model allometric linear. Hasil analisis digunakan untuk menghitung parameter $\mathrm{a}$ dan $\mathrm{b}$ melalui pengukuran perubahan berat dan panjang. Koreksi bias pada perubahan berat rata-rata dari unit logaritma digunakan untuk memprediksi berat pada parameter panjang sesuai dengan persamaan allometric berikut (Effendie
1979; Hukom, Purnama, dan Rahardjo 2006) :

$$
\mathrm{W}=\mathrm{a} \mathrm{Lb}
$$

Dimana W adalah berat ikan (g), L adalah panjang standar ikan $(\mathrm{mm})$, a dan b adalah konstanta.

Perhitungan rasio kelamin
dilakukan dengan membandingkan
jumlah antara ikan jantan dan betina per
bulan dan kelas panjang. Keseragaman
sebaran rasio kelamin dilakukan dengan
uji "Chi-Square" (Hedianto dan Purnamaningtyas 2013) dengan rumus :

$$
X^{2}=\frac{\left(f_{0}-f_{h}\right)^{2}}{f_{h}}
$$

Dimana:

$X^{2}=$ chi square
$f_{0}=$ frekuensi biota yang diamati
$f_{h}=$ frekuensi biota yang diharapkan

Nilai $X^{2}$ yang diperoleh dari perhitungan ini, dibandingkan dengan nilai $X^{2}$ tabel dengan taraf kepercayaan $95 \%$ dan derajat bebas $(\mathrm{db})=1$ (satu) dengan hipotesis:

$\mathrm{H}_{0}=$ tidak ada perbedaan yang nyata antara jumlah biota jantan dan betina $\mathrm{H}_{1}=$ terdapat perbedaan yang nyata antara jumlah biota jantan dan betina Jika, $\mathrm{X}^{2}$ hitung $<\mathrm{X}^{2}$ tabel $=\mathrm{H}_{0}$ diterima, $\mathrm{H}_{1}$ ditolak

$\mathrm{X}^{2}$ hitung $>\mathrm{X}^{2}$ tabel $=\mathrm{H}_{0}$ ditolak, $\mathrm{H}_{1}$ diterima

Analisis panjang ikan pertama kali tertangkap (LC) dianalisis berdasarkan metode Beverton dan Holt, 1957 (Ardelia, Vitner, dan Boer 2016):

$$
S L=\frac{1}{a+\exp (a-b L)}
$$


Nilai LC $50 \%$ diperoleh dengan memplotkan presentase frekuensi kumulatif ikan yang tertangkap dengan ukuran panjang standarnya, dimana titik potong antara kurva 50\% frekuensi kumulatif adalah panjang saat $50 \%$ ikan tertangkap. Adapun nilai LC dapat dihitung melalui rumus :

$$
\text { Lc }=\frac{-a}{b}
$$

Dimana :

LC = Panjang ikan pertama kali tertangkap (cm)

$\mathrm{a}=$ Intercept

b $=$ Slope (kemiringan)

Anasisis ukuran pertama kali matang gonad (Lm) dapat diduga dengan rumus Spearman-Karber (Wujdi dan Wudianto 2013) sebagai berikut :

$$
m=x k+\frac{d}{2}-\left(X \sum P i\right)
$$

\section{Keterangan:}

$\mathrm{M}$ = logaritma dari kelas panjang pada kematangannya yang pertama

$\mathrm{d}=$ selisih logaritma dari pertambahan nilai tengah panjang

$\mathrm{k}=$ jumlah kelas panjang

$x k=$ logaritma nilai tengah panjang dimana ikan $100 \%$ matang gonad (atau dimana $\mathrm{pi}=1)$.

\section{HASIL DAN PEMBAHASAN}

\section{Karakteristik Ikan Baronang di Maluku}

Berdasarkan hasil penelitian ditemukan dua spesies ikan baronang yang dominan. Identifikasi ikan baronang diambil buku identifikasi reef fishes (Allen dan Erdmann 2012) yang memuat gambar dan deskripsi ikan baronang
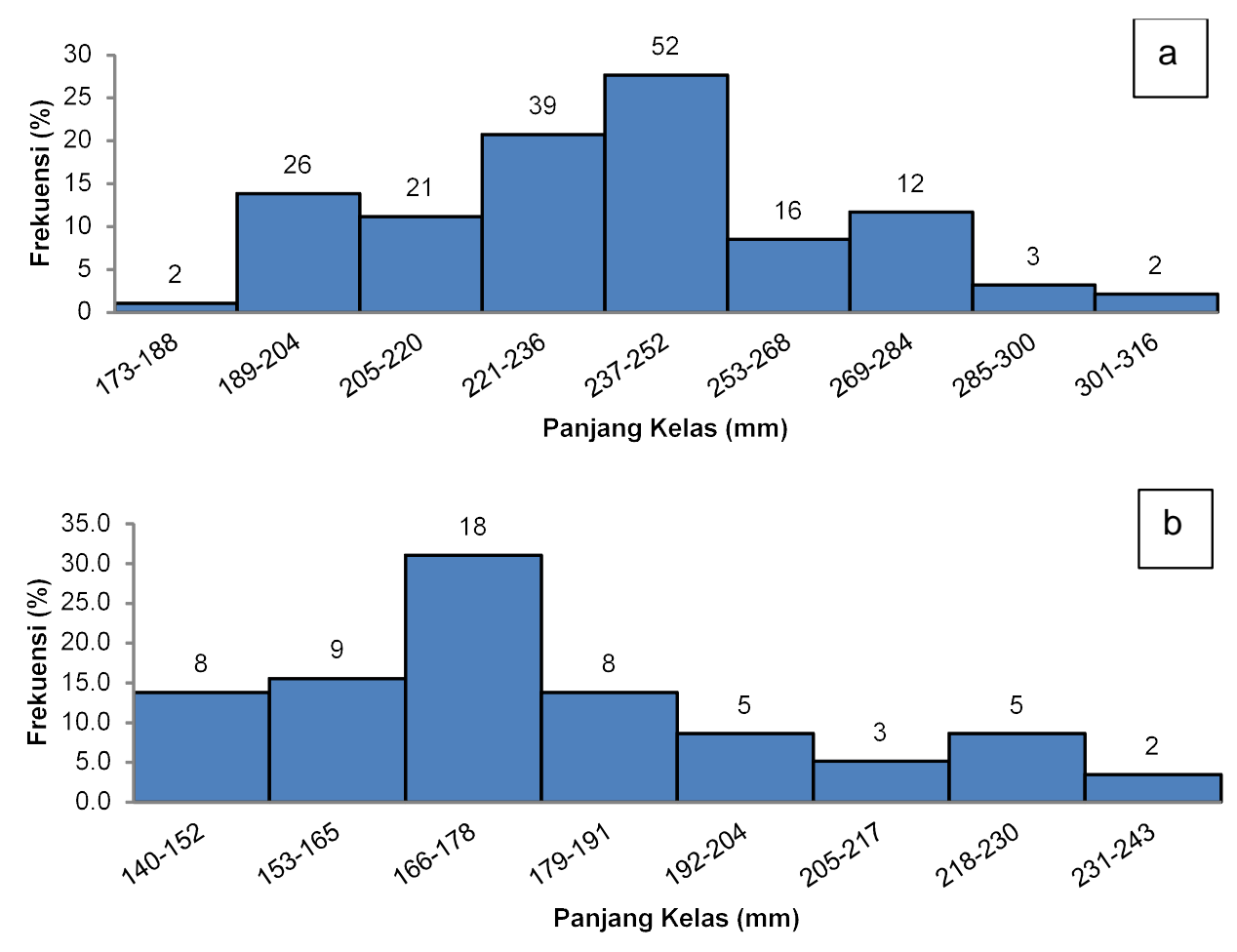

Gambar 2. Frekuensi panjang kelas a (S. lineatus) dan b (S. canaliculatus) 
yaitu Siganus lineatus dan Siganus canaliculatus.

Siganus lineatus memiliki tubuh berwarna abu-abu pucat dengan garisgaris oranye bergelombang, kadangkadang putus menjadi pola bintik-bintik pada punggungnya, dan memiliki bintik kuning besar di bagian bawah belakang dasar sirip dorsal. Mirip dengan $S$. guttatus, namun memiliki banyak garisgaris dibandingkan bintik-bintik. Mempunyai jumlah jari-jari sirip dorsal yaitu XIII,10, jari-jari sirip anal yaitu VII,9, jari-jari sirip ventral yaitu II,8 dan jari-jari sirip pektoral yaitu 16 .

Siganus canaliculatus memiliki warna abu-abu kehijauan sampai kuning kecoklatan dengan banyak bintik-bintik putih kebiruan, mempunyai tubuh oval, agak tinggi dan pipil. Bentuk lengkung kepala bagian atas agak cembung sampai di atas mata agak cekung, moncong tumpul dengan lubang hidung. Mempunyai jumlah jari-jari sirip dorsal yaitu XIII,10, jari-jari sirip anal yaitu VII,9, jari-jari sirip ventral yaitu II,8 dan jari-jari sirip pektoral yaitu 18 .

\section{Distribusi Frekuensi Panjang}

Berdasarkan pengamatan yang dilakukan, spesies yang dapat dianalisis lanjut hanya dua spesies saja, yaitu $S$. lineatus dan $S$. canaliculatus. Pada Gambar 2 (a) dapat dilihat bahwa dari 188 sampel yang didapatkan, panjang kelas yang mendominasi adalah 237.00$252.99 \mathrm{~mm}$ dengan 52 sampel. Berdasarkan Gambar 2 (b) dapat dilihat

Tabel 2. Hubungan Panjang Berat ikan baronang (Siganidae)

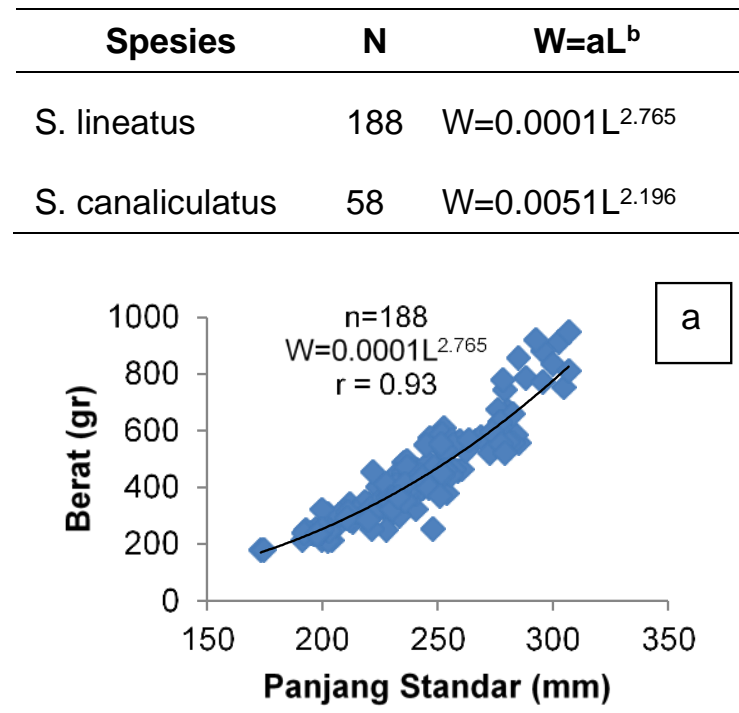

$\begin{array}{rll}\mathbf{t}_{\text {hitung }} & \mathbf{t}_{\text {tabel }} & \text { Pola Pertumbuhan } \\ 3.1063 & 1.962 & \text { Allometrik negatif } \\ 6.5370 & 2 & \text { Allometrik negatif }\end{array}$

Gambar 3. Hubungan panjang berat a (S. lineatus) dan b (S. canaliculatus) 
bahwa dari 58 sampel yang didapatkan, panjang kelas yang mendominasi adalah 166.00-178.99 mm sebanyak 18 sampel.

\section{Hubungan Panjang Berat}

Berdasarkan pengamatan yang dilakukan, spesies yang dapat dianalisis lanjut hanya dua spesies saja, yaitu $S$. lineatus dan $S$. canaliculatus. Hasil analisis regresi dan hubungan panjang berat sampel ikan baronang menghasilkan persamaan regresi seperti Tabel 2.

Dari hasil analisis yang disajikan pada Gambar 3a dapat dilihat hubungan panjang berat spesies $S$. lineatus adalah $W=0,0001 L^{2.765}$ yang berarti setiap pertambahan berat sebesar W, maka akan diikuti dengan pertambahan panjang standar sebesar $0,0001 \mathrm{~L}^{2.765}$. Setelah dilakukan uji t ( $\alpha$ 0.05) terhadap nilai $b$ diperoleh nilai thitung $=3,1063$ dan $t_{\text {tabel }}=1,962$. Karena $t_{\text {hitung }}>t$ tabel maka tolak $\mathrm{H}_{0}$, spesies $S$. lineatus memiliki pola pertumbuhan allometrik negatif yaitu $(b=2,765)$, artinya pertambahan panjang lebih cepat dari pada pertambahan berat. Dengan nilai $r$ sebesar 0,93 menunjukan bahwa adanya hubungan yang erat dan positif antara panjang dan berat.

Dari hasil analisis yang disajikan pada Gambar 3b. terlihat hubungan panjang berat spesies $S$. canaliculatus adalah $\quad W=0,0051 L^{2.196}$ yang menunjukkan setiap pertambahan berat sebesar W, akan diikuti dengan pertambahan panjang standar sebesar $0,0051 L^{2.196}$. Setelah dilakukan uji $t$ ( $\alpha$ $0.05)$ terhadap nilai b diperoleh nilai $t_{\text {hitung }}$ $=6,5370$ dan $t_{\text {tabel }}=2$. Karena thitung $>t_{\text {tabel }}$ maka tolak $H_{0}$, spesies $S$. canaliculatus memiliki pola pertumbuhan allometrik negatif yaitu $(b=2,196), \quad$ artinya pertambahan panjang lebih cepat dari pada pertambahan berat. Dengan nilai $r$ sebesar 0,93 menunjukan bahwa adanya hubungan yang erat dan positif.

\section{Sex Ratio}

Berdasarkan pengamatan yang dilakukan, spesies yang dapat dianalisis lanjut hanya dua spesies saja, yaitu $S$. lineatus dan $S$. canaliculatus. Pada spesies S. lineatus ditemukan 79 ekor jantan dan 109 ekor betina. Jumlah ikan baronang ( $S$. lineatus) jantan lebih sedikit dari ikan baronang ( $S$. lineatus) betina dengan sex ratio $1: 1,37$. Sedangkan pada spesies $S$. canaliculatus jumlahnya sama antara jantan dan betina yaitu sebanyak 29 ekor, dengan sex ratio 1:1.

Untuk mengetahui apakah perbandingan tersebut seimbang atau tidak, dilakukan pengujian perbandingan jenis kelamin dengan menggunakan uji chi-kuadrat, yang dapat dilihat pada Tabel 3. 
Tabel 3. Sex ratio ikan baronang (Siganidae)

\begin{tabular}{llccc}
\hline \multicolumn{1}{c}{ Spesies } & Jenis Kelamin & N & $\chi^{2}$ hitung & $\chi^{\mathbf{2}_{\text {tabel }}}$ \\
\hline \multirow{2}{*}{ S. lineatus } & Jantan & 79 & 4,7872 & \\
& Betina & 109 & & 3,8416 \\
\multirow{2}{*}{ S. canaliculatus } & Jantan & 29 & 0 & \\
& Betina & 29 & 0 & \\
\hline
\end{tabular}

Tabel 4. Tingkat Kematangan Gonad S. lineatus

\begin{tabular}{|c|c|c|c|c|c|c|c|c|c|}
\hline \multirow{3}{*}{ Jenis Kelamin } & \multicolumn{8}{|c|}{ Tingkat Kematangan Gonad } & \multirow{3}{*}{$\Sigma$ Sampe } \\
\hline & \multicolumn{2}{|c|}{ II } & \multicolumn{2}{|c|}{ III } & \multicolumn{2}{|c|}{ IV } & \multicolumn{2}{|c|}{ V } & \\
\hline & $\mathbf{n}$ & $\%$ & $\mathbf{n}$ & $\%$ & $\mathbf{n}$ & $\%$ & $\mathbf{n}$ & $\%$ & \\
\hline Jantan & 2 & 12 & 2 & 12 & 1 & 6 & 12 & 70 & 17 \\
\hline Betina & 0 & 0 & 3 & 14 & 4 & 18 & 15 & 68 & 22 \\
\hline Total & 2 & 5 & 5 & 13 & 5 & 13 & 27 & 69 & 39 \\
\hline
\end{tabular}

Hasil dari uji chi-kuadrat diperoleh bahwa $\chi^{2}$ hitung $S$. lineatus adalah 4,7872 dan $\chi^{2}$ tabel adalah 3,8416 sehingga $\chi^{2}$ hitung $>\chi_{\text {tabel }}^{2}=\mathrm{H}_{0}$ ditolak, yang berarti ada perbedaan nyata antara populasi jantan dan betina ikan baronang ( $S$. lineatus). Hasil dari uji chi-kuadrat diperoleh bahwa $\chi^{2}$ hitung S. canaliculatus adalah 0 dan $\chi^{2}$ tabel adalah 3,8416 sehingga $\chi^{2}$ hitung < $\chi^{2}$ tabel $=\mathrm{H}_{0}$ diterima, yang berarti tidak ada perbedaan nyata antara populasi jantan dan betina ikan baronang ( $S$. canaliculatus).

\section{Tingkat Kematangan Gonad}

Berdasarkan pengamatan yang dilakukan, spesies yang dapat dianalisis lanjut hanya dua spesies saja, yaitu $S$. lineatus dan S. Canaliculatus.
Pengamatan dilakukan terhadap 68 sampel ikan baronang terdiri dari 39 sampel S. lineatus dan 29 sampel $S$. canaliculatus.

Pada Tabel 4 dapat dilihat bahwa ikan baronang jantan ( $S$. lineatus) yang berada dalam kondisi sedang matang gonad (TKG III, IV dan V) sebanyak 15 ekor atau $88 \%$ dari jumlah ikan baronang jantan tersebut, kemudian sebanyak 2 ekor atau $12 \%$ berada dalam kondisi belum matang gonad (TKG II). Data tersebut menunjukkan bahwa yang sudah matang gonad lebih banyak tertangkap daripada yang belum matang gonad. Sedangkan ikan baronang betina ( $S$. lineatus) yang berada dalam kondisi sedang matang gonad (TKG III, IV dan V) sebanyak 22 ekor atau 100\% dari jumlah 
Tabel 5. Tingkat Kematangan Gonad S. canaliculatus

\begin{tabular}{|c|c|c|c|c|c|c|c|c|c|}
\hline \multirow{3}{*}{ Jenis Kelamin } & \multicolumn{8}{|c|}{ Tingkat Kematangan Gonad } & \multirow{3}{*}{$\Sigma$ Sampel } \\
\hline & \multicolumn{2}{|c|}{ II } & \multicolumn{2}{|c|}{ III } & \multicolumn{2}{|c|}{ IV } & \multicolumn{2}{|c|}{$\mathbf{v}$} & \\
\hline & $\mathbf{n}$ & $\%$ & $\mathbf{n}$ & $\%$ & $\mathbf{n}$ & $\%$ & $\mathbf{n}$ & $\%$ & \\
\hline Jantan & 0 & 0 & 0 & 0 & 1 & 8 & 12 & 92 & 13 \\
\hline Betina & 0 & 0 & 0 & 0 & 4 & 25 & 12 & 75 & 16 \\
\hline Total & 0 & 0 & 0 & 0 & 5 & 17 & 24 & 83 & 29 \\
\hline
\end{tabular}

Tabel 6. Nilai Lc dan Lm

\begin{tabular}{llccl}
\hline No & \multicolumn{1}{c}{ Spesies } & Jumlah Sampel & Lc $(\mathbf{m m})$ & \multicolumn{1}{c}{$\mathbf{L m}(\mathbf{m m})$} \\
\hline 1 & S. lineatus & 180 & 240,03 & $237,76(235,26-240,30)$ \\
2 & S. canaliculatus & 58 & 170,37 & 180,97 \\
\hline
\end{tabular}

ikan baronang betina tersebut. Data tersebut menunjukkan bahwa ikan baronang betina sudah matang gonad.

Pada Tabel 5 dapat dilihat bahwa ikan baronang jantan (S. canaliculatus) yang berada dalam kondisi sedang matang gonad (TKG IV dan V) sebanyak 13 ekor atau $100 \%$ dari jumlah ikan baronang jantan tersebut. Data tersebut menunjukkan bahwa ikan baronang jantan sudah matang gonad. Sedangkan ikan baronang betina ( $S$. canaliculatus) yang berada dalam kondisi sedang matang gonad (TKG IV dan V) sebanyak 16 ekor atau 100\% dari jumlah ikan baronang betina tersebut. Berdasarkan data tersebut menunjukkan bahwa seluruh ikan baronang ( $S$. canaliculatus) sudah matang gonad.

\section{Length at first capture (Lc) dan Length at first maturity (Lm)}

Berdasarkan pengamatan yang dilakukan, spesies yang dapat dianalisis lanjut hanya dua spesies saja, yaitu $S$. lineatus dan $S$. canaliculatus dikarenakan 4 spesies lainnya kekurangan sampel. Lc dan Lm pada $S$. lineatus dan $S$. canaliculatus dianalisis menggunakan panjang standar dengan alat tangkap gillnet dasar. Nilai Lc dan Lm dapat dilihat pada Tabel 6 .

Pada Tabel 6 dapat dilihat bahwa nilai Lc untuk ikan baronang ( $S$. lineatus) adalah 240,03 mm dengan nilai Lm sebesar 237,76 $\mathrm{mm} \quad(235,26-240,30$ $\mathrm{mm})$. Hasil analisis data menunjukkan ikan baronang ( $S$. lineatus) memiliki nilai (Lc>Lm) dimana ikan sudah memijah saat tertangkap. Sedangkan nilai LC pada ikan baronang (S. canaliculatus) 
adalah 170,37 mm dengan nilai Lm sebesar 180,97 mm. Hasil analisis data menunjukkan ikan baronang ( $S$. canaliculatus) memiliki nilai ( $\mathrm{Lc}<\mathrm{Lm})$ dimana ikan belum memijah pada saat tertangkap.

\section{Pembahasan}

Perbedaan frekuensi panjang ikan dalam suatu perairan antara lain ditentukan oleh ketersediaan makanan. Beberapa faktor yang berhubungan dengan makanan yang berpengaruh terhadap populasi antara lain jumlah, kualitas makanan, mudahnya tersedia makanan dan lama pengambilan makanan oleh ikan. Makanan yang telah digunakan akan mempengaruhi pertumbuhan, kematangan bagi tiap-tiap individu ikan serta keberhasilan hidupnya (survival) (Gani, Nilawati, dan Rizal 2015).

Pada perairan Teluk Totok, ikan baronang memiliki pola pertumbuhan allometrik positif dengan nilai $b>3(b=3,3)$ (Turang et al. 2019). Perbedaan nilai b tidak saja antara populasi dari spesies yang sama, tetapi juga antar populasi yang sama pada tahun tahun yang berbeda yang diduga dapat diasosiasikan dengan kondisi nutrisi. Hal ini bisa terjadi karena pengaruh faktor ekologis dan biologis. karena sering keadaan lingkungan berubah atau kondisi ikannya berubah, maka hubungan panjang berat akan sedikit menyimpang dari hukum kubik $(b \neq 3)$. Secara biologis nilai $b$ berhubungan dengan kondisi ikan, sementara kondisi ikan bergantung pada makanan, umur, jenis kelamin dan kematangan gonad (Panaha, Manginsela, dan Salaki 2018).

Pada perairan di Pulau Kei Maluku, Tenggara tidak ada perbedaan antara populasi jantan dan betina ikan baronang (S. lineatus) (Damora et al. 2016). Umumnya di alam nisbah kelamin ikan jantan dan ikan betina diperkirakan mendekati $1: 1$, suatu keadaan yang menunjukkan jumlah ikan jantan yang tertangkap secara relatif hampir sama banyaknya dengan jumlah ikan betina yang tertangkap. Kondisi yang seimbang ini diharapkan dapat mencegah terjadinya kepunahan populasi (Omar et al. 2014).

Ditemukannya ikan yang sudah mencapai TKG III dan IV merupakan indikator adanya ikan yang memijah pada perairan tersebut. Pemijahan ikan dilakukan pada saat kondisi lingkungan mendukung keberhasilan pemijahan dan kelangsungan hidup larva. Perbedaan awal mula suatu individu ikan mengalami matang gonad disebabkan umur, ukuran dan faktor fisiologi ikan itu sendiri (Sulistiono, Ichsan Ismail, dan Ernawati 2011; Tarigan, Bakti, dan Desrita 2017).

Kondisi penangkapan yang baik untuk menunjang proses rekruitmen 
adalah ketika ukuran panjang individu yang ditangkap sama dengan ukuran panjang pertama kali matang gonad (Lm) (Damora dan Ernawati 2011). S. lineatus yang tertangkap menunjukkan nilai Lc>Lm dan dapat dikatakan sebagai hasil penangkapan yang baik. Nilai Lc $<\mathrm{Lm}$ pada $S$. canaliculatus menunjukkan bahwa hasil tangkapan didominasi oleh ikan-ikan yang belum pernah memijah. Secara biologis, jika hal tersebut dibiarkan terus menerus, akan berdampak buruk pada berkelanjutan populasi ikan baronang. Penangkapan ikan yang didominasi oleh ikan-ikan kecil, akan menyebabkan terjadinya growth overfishing (Agustina, Boer, dan Fahrudin 2015).

\section{SIMPULAN}

Hasil dari penelitian ini menunjukkan bahwa $S$. lineatus dan $S$. canaliculatus memiliki pola pertumbuhan allometrik negatif. Nisbah kelamin pada $S$. lineatus dan $S$. canaliculatus berurutan yaitu 1:1,37 dan 1:1. Tingkat kematangan gonad yang diamati menggunakan TKG dari Cassie menujukkan Siganus lineatus dan Siganus canaliculatus lebih dominan pada TKG V. Analisis kondisi biologis menggunakan kurva logistik dan rumus Spearman-Karber mengindikasikan hasil tangkapan ikan $S$. lineatus didominasi ikan-ikan yang sudah memijah sedangkan pada $S$. canaliculatus didominasi ikan-ikan yang belum memijah.

\section{PERSANTUNAN}

Terima kasih diucapkan kepada DKP Provinsi Maluku, DKP Kota Ambon dan DKP Kabupaten Kepuluan Aru, dan Corps Coral AUP-STP atas bantuan yang diberikan selama dalam penelitian. Ucapan terima kasih juga kami sampaikan kepada civitas akademika Sekolah Tinggi Perikanan, masyarakat di Maluku serta pihak lainnya yang tidak bisa disebutkan satu persatu.

\section{DAFTAR PUSTAKA}

Adam, Lukman. 2016. “Kebijakan Pelarangan Penangkapan Ikan Tuna Sirip Kuning Analisis Dampak dan Solusinya." Jurnal Ekonomi dan Kebijakan Publik 7:215-27.

Agustina, Siska, Menofatria Boer, dan Achmad Fahrudin. 2015. "Dinamika Populasi Sumber Daya Ikan Layur (Lepturacanthus savala) di Perairan Selat Sunda." Marine Fisheries: Journal of Marine Fisheries Technology and Management 6(1):77.

Allen, Gerald R. dan Mark V. Erdmann. 2012. "Reef Fishes of The East Indies." III.

Ardelia, Vera, Yon Vitner, dan Mennofatria Boer. 2016. "Biologi 
Reproduksi Ikan Tongkol Euthynnus affinis Di Perairan Selat Sunda." Jurnal IImu dan Teknologi Kelautan Tropis 8(2):689-700.

Bank Indonesia. 2007. Perkembangan

Perekonomian Daerah Provinsi

Maluku.

Bawole, Dionisius dan Yolanda M. T. N.

Apituley. 2010. "Maluku Sebagai

Lumbung Ikan Nasional: Tinjuan

Atas Suatu Kebijakan." 239-46.

Burhanuddin, Andi Iqbal. 2005. "Ikan-

Ikan Beronang (Siganidae) di Teluk

Tomini, Gorontalo." Jurnal Iktiologi

Indonesia (2001):2003-6.

Burhanudin, Andi lqbal, Budimawan, dan

Sahabuddin. 2014. "The Rabbit-

Fishes (Family Siganidae) from the

Coast of Sulawesi, Indonesia." International Joournal of Plant, Animal and Enviromental Science 95-102.

Damora, A., I. A. Fikri, I. M. Teneu, P. Lestari, T. H. Iqbal, dan M. Yusuf. 2016. "Reproductive Biology of Three Reef Fish Species From Kei Islands, Southeast Maluku, Indonesia." IOP Conference Series: Earth and Environmental Science 216:012028.

Damora, Adrian dan Tri Ernawati. 2011.

"Beberapa Aspek Biologi Ikan Beloso(Saurida micropectoralis) diperairan utara Jawa Tengah."
BAWAL 3(6):363-67.

Diane J. Bray. 2019. "Rabbitfishes, Siganidae in Fishes of Australia." 17:2019.

Dinas Penanaman Modal dan Pelayanan Terpadu Satu Pintu Provinsi Maluku. 2012. "Perikanan Maluku." $1-2$.

Effendie, M. I. 1979. Metoda Biologi Perikanan. Bogor (ID): Yayasan Dewi Sri.

Fakhri, Saiyaf, Indah Riyantini, Donny Juliandri, dan Herman Hamdan. 2016. "Korelasi Kelimpahan Ikan Baronang ( Siganus Spp ) Dengan Ekosistem Padang Lamun Di Perairan Pulau Pramuka Taman Nasional Kepulauan Seribu." VII(1):165-71.

Froese, R. dan D. Pauly. 2018. "Siganus." www. fishbase.org 1-5.

Gani, Abdul, Jusri Nilawati, dan Achmad Rizal. 2015. "STUDI HABITAT DAN KEBIASAAN MAKANAN ( FOOD HABIT ) IKAN RONO LINDU ( Oryzias sarasinorum POPTA , 1905 )." 9-18.

Hedianto, Dimas Angga dan Sri Endah Purnamaningtyas. 2013. "Biologi Reproduksi Ikan Golsom (Hemichromis Elongatus, Guichenot 1861) Di Waduk Cirata, Jawa Barat." BAWAL Widya Riset Perikanan Tangkap 5(3):159-66. 
Hikmayani, Yayan dan Siti Hajar Suryawati. 2016. "Evaluasi Kesiapan Kota Ambon dalam Mendukung Maluku Sebagai Lumbung Ikan Nasioal." Jurnal Kebijakan Sosek KP (021):97-110. Hukom, Frensly Damianus, Dewi Ratih Purnama, dan MF Rahardjo. 2006. “Tingkat Kematangan Gonad, Faktor Kondisi, Dan Hubungan Panjang-Berat Ikan Tajuk (Aphareus Rutilans Cuvier, 1830) di Perairan Laut Dalam Palabuhanratu, Jawa Barat." Jurnal Iktiologi Indonesia 6.

Latuconsina, Husain dan Jahra

Wasahua. 2015. "Nisbah Kelamin dan Ukuran Pertama Kali Matang Gonad Ikan Samandar (Siganus Canaliculatus Park 1797) Pada Perairan Pulau Buntal-Teluk Kotania Kabupaten Seram Bagian Barat." Hal. 17-25 in Seminar Nasional Tahunan XII Hasil Penelitian Perikanan dan Kelautan. Yogyakarta (ID).

Luhur, Estu Sri dan Risna Yusuf. 2017.

"Analisis Rantai Nilai Ikan Cakalang di Kota Ambon, Maluku." Jurnal Sosial Ekonomi 12.

Malik, Fikri R. 2013. "Kajian Bebebrapa Alat Tangkap Bubu Dasar di Perairan Kepuluan Ternate Provinsi Maluku Utara." Jurnal IImiah agribisnis dan Perikanan.
Miftahussalam. 2013. "Kajian Pengelolaan Perikanan Wilayah Laut Maluku."

Munira, Sulistiono, dan Zairion. 2010. "Hubungan Panjang-Bobot dan Pertumbuhan Ikan Baronang Siganus Canaliculatus (Park,1797) di Padang Lamun Selat Lonthoir, Kepuluan Banda, Maluku." Jurnal Iktiologi Indonesia 10(2):153-63.

Omar, Sharifuddin Bin Andy, Kariyanti, Joeharnani Tresnati, Moh Tauhid Umar, dan Syarifuddin Kune. 2014. "Nisbah Kelamin dan Ukuran Pertama Kali Matang Gonad Ikan Endemik

Beseng-Beseng, Marosatherina ladigesi (Ahl, 1936), di Sungai Bantimurung dan Sungai Pattunuang Asue, Kabupaten Maros, Sulawesi Selatan." Seminar Nasional Tahunan XI Hasil Penelitian Perikanan dan Kelautan 2014 08(August 2014).

Panaha, Mediyanto Samuel, Fransine B. Manginsela, dan Meiske S. Salaki. 2018. "Tampilan Biologis Ikan Layang Decapterus Macrosoma Bleeker, 1851 Di Perairan Tanjung Salonggar Melonguane Kabupaten Kepulauan Talaud." Jurnal IImiah PLatax 6(1):61-73.

Pratomo, Arief, Dony Apdillah, Falmy Yandri, dan Lily Viruly. 2006. "Kondisi Ikan Herbivora di Ekosistem Terumbu Karang 
Perairan Teluk Bakau, Pulau Bintan."

Randall, John E. dan Michel Kulbicki. 2005. "Siganus woodlandi, new species of rabbitfish ( Siganidae ) from New Caledonia by." 29(1):18589.

Rembet, Unstain NWJ, Mennofatria Boer, Dietriech G. Bengen, dan Achmad Fahrudin. 2011. "Stuktur Komunitas Ikan Target di Terumbu Karang Pulau dan Putus-Putus Sulawesi." Jurnal Perikanan dan Kelautan Tropis VII:60-65.

Sulistiono, Muhammad Ichsan Ismail, dan Yunizar Ernawati. 2011. "Tingkat Kematangan Gonad Ikan Tembang (Clupea platygaster) di Perairan Ujung Pangkah, Gresik, Jawa Timur." Journal of Biota 16(1):26-38.

Suryawati, Siti Hajar dan Tajerin. 2015. "Penilaian Kesiapan Maluku Sebagai Lumbung Ikan Nasional." Jurnal Sosial Ekonomi 1-19.

Tarigan, Adriana, Darma Bakti, dan Desrita Desrita. 2017. "Tangkapan dan Tingkat Kematangan Gonad Ikan Selar Kuning (Selariodes leptolepis) di Perairan Selat Malaka." Acta Aquatica: Aquatic Sciences Journal 4(2):44.

Tuegeh, Suleiman, Ferdinand F. Tilaar, dan Gaspar D. Manu. 2012.
"Beberapa Aspek Biologi Ikan Baronang (Siganus vermiculatus) di Perairan Arakan Kecamatan Tatapan Kabupaten Minahasa Selatan." Jurnal IImiah Platax I(September):12-18.

Turang, Rivany, Victor N. R. Watung, dan Anneke V. Lohoo. 2019. "Struktur Ukuran, Pola Pertumbuhan dan Faktor Kondisi Ikan Baronang (Siganus canaliculatus) dari Perairan Teluk Totok Kecamatan Ratatotok Kabupaten Minahasa Tenggara." Jurnal IImiah Platax 7(1):193-201.

Woodland, David J. dan R. Charles Anderson. 2014. "Description of a new species of rabbitfish (Perciformes: Siganidae) from southern India, Sri Lanka and the Maldives." (May).

Wujdi, Arief dan Wudianto. 2013. "Biologi Reproduksi dan Musim Pemijahan Ikan Lemuru (Sardinella lemuru Bleeker 1853) diperairan Selat bali." BAWAL 5(April):49-57.

WWF-Indonesia. 2015. "Ikan kakatua dan Baronang." www.wwf.or.id 1. 